\title{
VaProS: a database-integration approach for protein/genome information retrieval
}

\author{
Takashi Gojobori $^{1,2} \cdot$ Kazuho Ikeo $^{2} \cdot$ Yukie Katayama $^{3}$ 'Takeshi Kawabata ${ }^{4} \cdot$ Akira R. Kinjo $^{4} \cdot$ Kengo Kinoshita $^{5,6}$. \\ Yeondae Kwon ${ }^{3} \cdot$ Ohsuke Migita $^{7,8} \cdot$ Hisashi Mizutani $^{2} \cdot$ Masafumi Muraoka $^{2} \cdot$ Koji Nagata $^{3} \cdot$ Satoshi Omori $^{5}$ • \\ Hideaki Sugawara $^{2} \cdot$ Daichi Yamada $^{9} \cdot$ Kei Yura $^{2,9}$
}

Received: 3 September 2016 / Accepted: 5 December 2016 / Published online: 23 December 2016

(c) The Author(s) 2016. This article is published with open access at Springerlink.com

\begin{abstract}
Life science research now heavily relies on all sorts of databases for genome sequences, transcription, protein three-dimensional (3D) structures, protein-protein interactions, phenotypes and so forth. The knowledge accumulated by all the omics research is so vast that a computer-aided search of data is now a prerequisite for starting a new study. In addition, a combinatory search throughout these databases has a chance to extract new ideas and new hypotheses that can be examined by wet-lab experiments. By virtually integrating the related databases on the Internet, we have built a new web application that facilitates life
\end{abstract}

Kei Yura

yura.kei@ocha.ac.jp

1 Computational Bioscience Research Center, Biological and Environmental Sciences and Engineering, King Abdullah University of Science and Technology, Thuwal 23955-6900, Saudi Arabia

2 National Institute of Genetics, Shizuoka, 411-8540 Mishima, Japan

3 Graduate School of Agricultural and Life Sciences, University of Tokyo, Bunkyo, Tokyo 113-8657, Japan

4 Institute for Protein Research, Osaka University, Suita, Osaka 565-0871, Japan

5 Graduate School of Information Sciences, Tohoku University, Miyagi, Sendai 980-8597, Japan

6 Tohoku Medical Megabank Organization, Tohoku University, Miyagi, Sendai 980-8573, Japan

7 Department of Maternal-Fetal Biology, National Research Institute for Child Health and Development, Setagaya, Tokyo 157-8535, Japan

8 Department of Pediatrics, St. Marianna University School of Medicine, Miyamae, Kawasaki 216-8511, Japan

9 Center for Informational Biology, Ochanomizu University, 2-1-1, Otsuka, Bunkyo, Tokyo 112-8610, Japan science researchers for retrieving experts' knowledge stored in the databases and for building a new hypothesis of the research target. This web application, named VaProS, puts stress on the interconnection between the functional information of genome sequences and protein 3D structures, such as structural effect of the gene mutation. In this manuscript, we present the notion of VaProS, the databases and tools that can be accessed without any knowledge of database locations and data formats, and the power of search exemplified in quest of the molecular mechanisms of lysosomal storage disease. VaProS can be freely accessed at http://p4d-info.nig.ac.jp/vapros/.

Keywords Big data analysis - Database integration . Lysosomal storage disease $\cdot$ Protein 3D structure

\section{Introduction}

The advance of the molecular biology has yielded a huge amount of biological data including DNA/RNA/protein sequences [1-3], their expression levels [4], difference in the sequences of individuals [5], three-dimensional (3D) structures of the biomolecules [6], phenotypes of the organisms [7] and so forth. These data have been stored in independent databases located on the Internet and researchers exploit these databases for new knowledge of the target of their study. Database mining facilitates the process of knowledge acquisition and that of building new hypotheses for planning new experiments [8].

The expansion of the data size has been coped with the increase in the size of the storage and with invention of a new algorithm for searching the whole data swiftly. One of the famous examples of the tool for quick search of a database in this field is BLAST [9], a tool to search similar 
sequences out of the huge nucleotide/amino acid sequence databases. Further expansion of the size of the independent database and the increase in the variety of databases may have enhanced chances for performing novel experiments by extending the scope of hypotheses, yet the lack of technology for integrating different types of databases and of an application for searching the multiple databases have precluded extensive application of this approach. The researchers aiming for an integrated search of different databases should approach the databases one by one, learn how to use each database and obtain information relevant for their studies. The users then integrate the data obtained from different databases by themselves. This process evidently requires tedious labour as well as skills for manipulating data in different formats. Hence, the biggest hurdle that we have to overcome in the current life science activity is the complexity in integrating databases in a way that enables us to come up with novel ideas and hypotheses. Once the up-to-date data is comprehensively integrated, then researchers with an experience in a specific field can start deducing a hypothesis in a data-driven manner.

The effort for integrating the management of different databases has been made by a number of groups [10-14]. Linking data with a common framework is one of the possible approaches, and the Semantic Web technologies are becoming increasingly popular in recent years [15]. While the Semantic Web technologies based on linked open data and ontologies are a promising approach, extremely diverse set of ontologies as well as non-uniform uses of URI (Uniform Resource Identifiers) to describe identical resources by different parties make it difficult to integrate various information resources without extensive manual intervention. Although some efforts have been dedicated to solve these difficulties (e.g., http://identifiers.org), it will take time for the research community to agree on a unified convention.

To overcome these difficulties in a search of multiple databases in the information of life science, we started developing a new type of application that searches databases in different locations simultaneously by a simple search query and displays the result in a simple interface at http://p4d-info.nig.ac.jp/vapros/. We named the application VaProS, VAriation effect of PROtein Structure and function. The name derived from the aim of the application, namely to focus on analysing effects of DNA sequence variations on protein structures and function. VaProS aims to realize an idea of "data cloud", that is to retrieve data without any knowledge of databases scattered in the Internet.

The idea embedded in VaProS that is different from other general database integration efforts is that VaProS makes much of the relationship among the biological molecules and phenomena. The relationship is governed by the central dogma; hence all the incidents can be described in either gene-centered or protein-centered manner. Phenotypic changes of an organism likely derive from changes in the biological system of the organism, which is sustained by the network of biomolecules and those biomolecules are ultimately encoded in DNA. This flow of information is nothing but the opposite direction of the central dogma, and hence the organization of data and databases in VaProS follows the information flow in the central dogma. Technically, the search results of the variety of databases are interconnected using the protein as a hub of information. In the following sections, the detail of VaProS and the example of the usage are presented.

\section{Materials and methods}

\section{Databases and tools on the internet}

Table 1 lists the databases that are integrated on VaProS and the tools that visualize the search results. There are 16 databases and 15 tools of which VaProS are made. The latest information of the databases, namely the version and the size, is given at http://p4d-info.nig.ac.jp/vapros/statistics.html. The integration of the databases took the form of either dynamic link or a data copy from the original site to the local site of VaProS. Ideally, all the databases should be accessed dynamically to avoid time lag of the data and to save the local disk space, but such dynamic access often sacrifices a prompt response to a query. Therefore, we downloaded the part of the data from each database and achieved an optimum response speed. The data update is scheduled once in every six month to keep abreast with the latest data in all the databases. VaProS deals with the data of humans, rats and mice and focuses on phenomena related to humans.

\section{Data integration and data presentation in VaProS}

VaProS is unique in the style of data integration. VaProS tries to integrate different databases dynamically and relationship amongst the data in the databases is taken by UniProt accession key. Central dogma guarantees the relationship between biomolecules in the organisms, hence all the phenotypes should basically stem from the perturbation on biomolecules. Therefore, phenomena observed in the organization can be tagged to either DNA or protein. We chose a protein identifier to tag all the other data, because VaProS is aimed for the analysis of protein variation.

UniProtKB [2], GeneCards [12] and Cosmic [13] assume a similar approach for the integration of relevant data. VaProS put stress on a graphical presentation of the search results as found in "Molecular Interactions" and "TagCloud", and on the analyses on protein 3D structures 
Table 1 Components of VaProS

\begin{tabular}{|c|c|c|c|c|c|c|}
\hline $\mathrm{DB} /$ tool name & Data resource & Search tool & $\begin{array}{l}\text { Data/function used in } \\
\text { VaProS }\end{array}$ & Method of access & Original location & Reference \\
\hline EntrezGene & $\checkmark$ & & $\begin{array}{l}\text { Nomenclature, reference } \\
\text { and other biological infor- } \\
\text { mation of genes }\end{array}$ & Copy and link & $\begin{array}{l}\text { http://www.ncbi.nlm.nih. } \\
\text { gov/gene/ }\end{array}$ & [16] \\
\hline UniprotKB & $\checkmark$ & & $\begin{array}{l}\text { Amino acid sequences with } \\
\text { biological annotation } \\
\text { such as ontology and clas- } \\
\text { sification }\end{array}$ & Copy and link & http://www.uniprot.org/ & [17] \\
\hline BioGRID & $\checkmark$ & & $\begin{array}{l}\text { Genetic and protein interac- } \\
\text { tions with curation based } \\
\text { on biomedical literature }\end{array}$ & Copy and link & http://thebiogrid.org/ & [18] \\
\hline ChEMBL & $\checkmark$ & & $\begin{array}{c}\text { Drug-like small molecules } \\
\text { with interacting proteins }\end{array}$ & Copy and link & $\begin{array}{l}\text { https://www.ebi.ac.uk/ } \\
\text { chembl/ }\end{array}$ & [19] \\
\hline DrugBank & $\checkmark$ & & $\begin{array}{l}\text { Drug molecules com- } \\
\text { bined with drug target } \\
\text { informtaion }\end{array}$ & Copy and link & http://www.drugbank.ca/ & {$[20]$} \\
\hline IntAct & $\checkmark$ & & $\begin{array}{l}\text { Molecular interactions } \\
\text { obtained from literature } \\
\text { and direct submission }\end{array}$ & Copy and link & http://www.ebi.ac.uk/intact/ & {$[21]$} \\
\hline PID (NDEx) & $\checkmark$ & & $\begin{array}{l}\text { Biological interaction data } \\
\text { of proteins }\end{array}$ & Copy and link & http://www.ndexbio.org/\#/ & {$[22]$} \\
\hline Reactome & $\checkmark$ & & Biological pathway data & Copy and link & http://www.reactome.org/ & {$[23]$} \\
\hline OMIM & $\checkmark$ & & $\begin{array}{l}\text { Mendelian disease related } \\
\text { phenotype and its causa- } \\
\text { tive gene }\end{array}$ & Link & http://www.omim.org/ & [7] \\
\hline hGtoP & $\checkmark$ & $\checkmark$ & $\begin{array}{l}\text { 3D structural and compara- } \\
\text { tive genomics annotations } \\
\text { of humans, mice and rats }\end{array}$ & Link & $\begin{array}{l}\text { http://p4d-info.nig.ac.jp/ } \\
\text { hGTOP/ }\end{array}$ & {$[24]$} \\
\hline Natural Ligand Database & $\checkmark$ & $\checkmark$ & $\begin{array}{l}\text { 3D models of proteins and } \\
\text { their natural ligands reg- } \\
\text { istered in KEGG reaction } \\
\text { database }\end{array}$ & Link & http://nldb.hgc.jp/nldb/ & {$[25]$} \\
\hline COXPRESdb & $\checkmark$ & $\checkmark$ & $\begin{array}{l}\text { Relationship of gene } \\
\text { expression based on } \\
\text { RNAseq and microarray } \\
\text { data }\end{array}$ & Link & http://coxpresdb.jp/ & {$[26]$} \\
\hline Mutation@A Glance & $\checkmark$ & $\checkmark$ & $\begin{array}{l}\text { Genetic variants on proteins } \\
\text { including disease-causing } \\
\text { mutations observed in } \\
\text { humans }\end{array}$ & Link & $\begin{array}{l}\text { http://harrier.nagahama-i- } \\
\text { bio.ac.jp/mutation/ }\end{array}$ & {$[27]$} \\
\hline 3D Interaction & $\checkmark$ & $\checkmark$ & $\begin{array}{l}\text { Models of protein 3D } \\
\text { structure and the structure } \\
\text { in complex with other } \\
\text { molecules }\end{array}$ & Link & http://homcos.pdbj.org/ & {$[28]$} \\
\hline Autophagy DB & $\checkmark$ & $\checkmark$ & $\begin{array}{l}\text { List of genes and proteins } \\
\text { for autophagy }\end{array}$ & Built-in & $\begin{array}{l}\text { http://www.tanpaku.org/ } \\
\text { autophagy/ }\end{array}$ & [29] \\
\hline GNP expression & $\checkmark$ & $\checkmark$ & $\begin{array}{l}\text { Genes clustered by expres- } \\
\text { sion pattern showning } \\
\text { co-regulation and anti- } \\
\text { regulation }\end{array}$ & Built-in & $\begin{array}{l}\text { http://genomenetwork.nig. } \\
\text { ac.jp/ }\end{array}$ & - \\
\hline Molecular Interactions & & $\checkmark$ & $\begin{array}{l}\text { Graphic tool for interac- } \\
\text { tion networks of proteins, } \\
\text { compounds and pheno- } \\
\text { types }\end{array}$ & Built-in & - & - \\
\hline
\end{tabular}


Table 1 (continued)

\begin{tabular}{|c|c|c|c|c|c|c|}
\hline DB/tool name & Data resource & Search tool & $\begin{array}{l}\text { Data/function used in } \\
\text { VaProS }\end{array}$ & Method of access & Original location & Reference \\
\hline TagCloud & & $\checkmark$ & $\begin{array}{l}\text { Graphic tool to display } \\
\text { frequency of words in the } \\
\text { titles of papers registered } \\
\text { in UniProt }\end{array}$ & Built-in & - & - \\
\hline Pathway DB & & $\checkmark$ & $\begin{array}{l}\text { Finder of the related path- } \\
\text { ways from the databases } \\
\text { in use }\end{array}$ & Built-in & - & - \\
\hline Phenotype & & $\checkmark$ & $\begin{array}{l}\text { Finder of medelian disease } \\
\text { related to the protein/gene } \\
\text { in query }\end{array}$ & Built-in & - & - \\
\hline Cis-finder & & $\checkmark$ & $\begin{array}{l}\text { Finder of the cis element } \\
\text { candidate motifs in DNA } \\
\text { sequence }\end{array}$ & Built-in & - & - \\
\hline S-VAR & & $\checkmark$ & $\begin{array}{l}\text { Evaluator of the impact of } \\
\text { missense mutation in a } \\
\text { protein }\end{array}$ & Link & $\begin{array}{l}\text { http://p4d-info.nig.ac.jp/s- } \\
\text { var/ }\end{array}$ & - \\
\hline Genome explorer & & $\checkmark$ & $\begin{array}{l}\text { Annotator of genes with } \\
\text { transcription start sites } \\
\text { and other biological } \\
\text { function }\end{array}$ & Built-in & $\begin{array}{l}\text { http://genomenetwork.nig. } \\
\text { ac.jp/ }\end{array}$ & - \\
\hline NOREN & & $\checkmark$ & $\begin{array}{l}\text { ID connector from UniProt } \\
\text { AC to all the other IDs of } \\
\text { the databases in use }\end{array}$ & Built-in & http://cib.cf.ocha.ac.jp/DC/ & - \\
\hline
\end{tabular}

as found in "hGtoP", "3D Interaction" and "Natural Ligand Database".

\section{Search method}

VaProS accepts keywords, DNA/protein sequence, EntrezGene ID and UniProtKB accession as a query (Fig. 1). A keyword can be a gene name, a protein name, a ligand (drug) name, a disease (phenotype) name and an identifier found in the databases. Input of the keywords is assisted by a keyword-suggestion function. Incomplete input makes VaProS find a related keywords in the keyword database and it shows a list of candidate words below the query input window. Once the Search button is pressed, VaProS throws the input data to NOREN, an original tool to search for whole IDs in the databases related to the query. NOREN is based on the ID mapping table provided by UniProtKB [2], and BLAST [9]. The result of the query is presented as a list of candidates to the user. The candidate list is categorized into three different types, namely Gene/Protein, Ligand and Phenotype (Fig. 2). The user may select the most relevant element in the list, press "Details (Go)" button and obtain the results of the search done by IDs relevant to the keywords (Fig. 3). The results are presented through the tools tabulated in Table 1 . The search results shown by each tool can be opened by clicking the corresponding icon on the left in Fig. 3.

\section{Results and discussion}

We explored the current knowledge on lysosomal storage diseases (LSDs) and built a tenable hypothesis as a case study to show the usage of VaProS. The similar analyses can be conducted on different diseases by accessing http:// p4d-info.nig.ac.jp/vapros.

\section{Lysosomal storage disease}

Lysosomes are subcellular organelles responsible for the physiological turnover of the cell constituents. They contain catabolic enzymes that require a low $\mathrm{pH}$ environment for their optimal function. LSDs are a heterogeneous group of more than 50 rare inherited disorders characterized by the accumulation of undigested or partially digested macromolecules (Table 2). LSDs ultimately result in cellular dysfunction and clinical abnormalities. LSDs are caused by deficiencies or defects in enzymes for lysosomes, in proteins necessary for the normal post-translational modification of lysosomal enzymes, in the activator proteins 

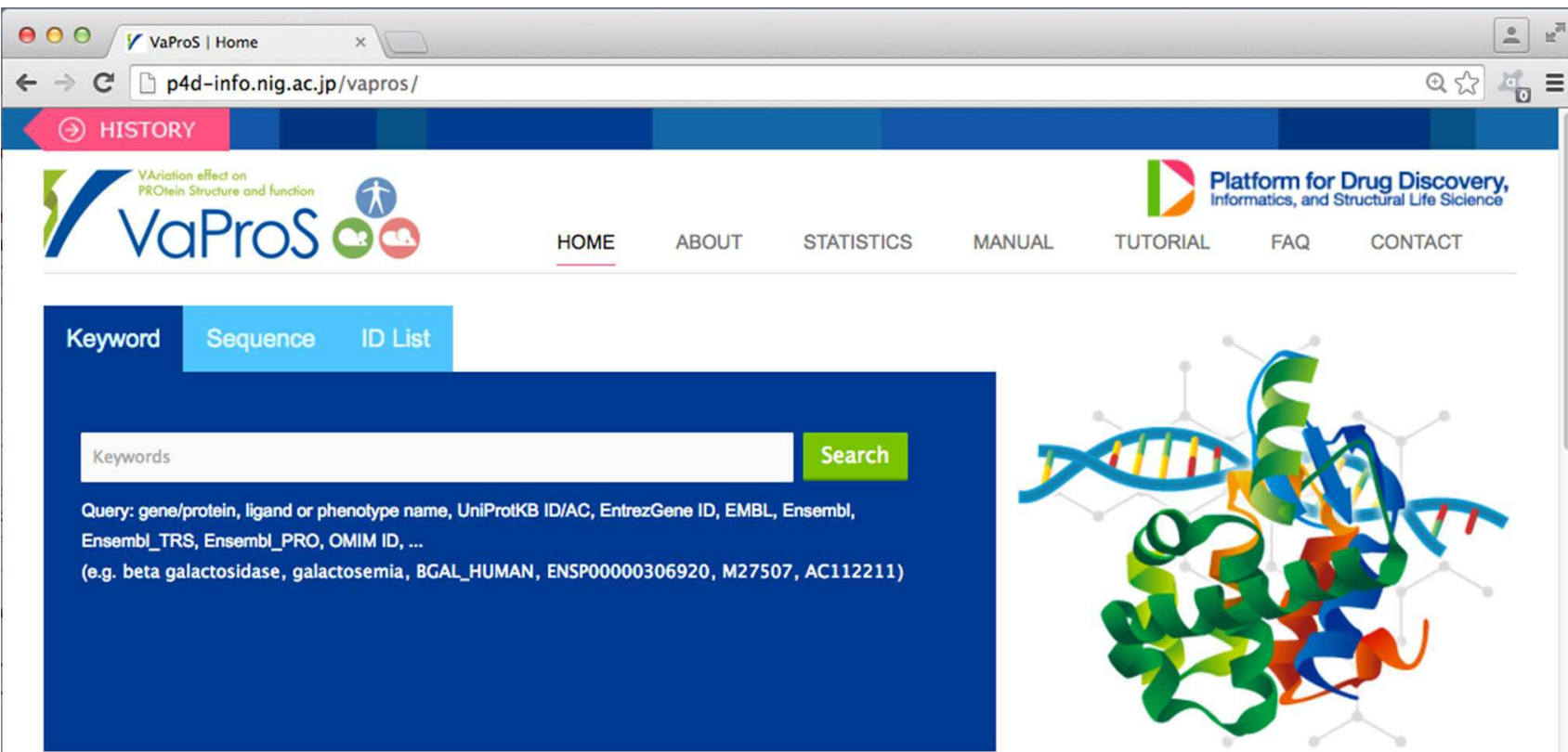

\section{VaProS: VAriation effect on PROtein Structure and function}

VaProS, VAriation effect on PROtein Structure and function, is a new data cloud for Structural Life Science and is the core technology to lead the collaboration between the discipline in Structural Biology and the whole Life Sciences. Led by the initiative of National Institute of Genetics, VaProS has been developed around the Integrated Structural Biology Database at Institute for Protein Research in Osaka University, together with the selected outcomes from Protein 3000 Project, Targeted Proteins Research Program, Genome Network Project and Cell Innovation Project. more...

Fig. 1 The top page of VaProS located at http://p4d-info.nig.ac.jp/vapros

of lysosomal enzymes, and in the proteins important for proper intracellular trafficking between the lysosome and other intracellular compartments. The individual diseases are rare, but LSDs as a group affects many people around the world with a frequency of about one in every 7000-8000 live births [30, 31].

\section{Search in the first step}

A search by a keyword "gangliosidosis", one of the major groups in LSDs, resulted in six candidates as shown in Fig. 4. As shown in Table 2, gangliosidoses are classified into two types, GM1 and GM2, both of which are further classified into three subtypes. The estimated incidence of GM1-gangliosidosis is 1 per 100,000 to 200,000 births, and those of GM2-gangliosidosis are 1 per 360,000 births for Tay-Sachs disease and 1 per 310,000 or $1,000,000$ births for Sandhoff disease. GM2-gangliosidosis AB variant is extremely rare [32]. Each line in the search result happened to correspond to an individual entry of genetic diseases/ disorders in OMIM database [7]. The three types in GM1gangliosidoses (types I, II, and III) were related to the same
"Molecule Symbol", namely GLB1 gene, but Tay-Sachs disease, Sandhoff disease and AB variant in GM2-gangliosidoses were related to HEXA, HEXB and GM2A genes, respectively. Each gene was linked to the databases listed in Table 1. Ticking the far left box in Fig. 4 and pressing "Details (Go)" button on the top led the user to the further detail of the selected item. In the following section, the search result of each tool listed in Table 1 is explained.

\section{Molecular interactions}

The interaction network of the proteins encoded in HEXA and HEXB was found in "Molecular Interactions" window (Fig. 5). This window can be displayed by ticking both HEXA and HEXB in the table shown in Fig. 4 and pressing "Details (Go)" button. A protein is represented with a big node and a ligand is represented with a small node. A protein-protein/ligand interaction is represented with an edge. Figure 5 tells that eight proteins and four ligands interact both with HEXA and HEXB, and each protein interacts with a number of other proteins and ligands. These interactions were extracted from different 


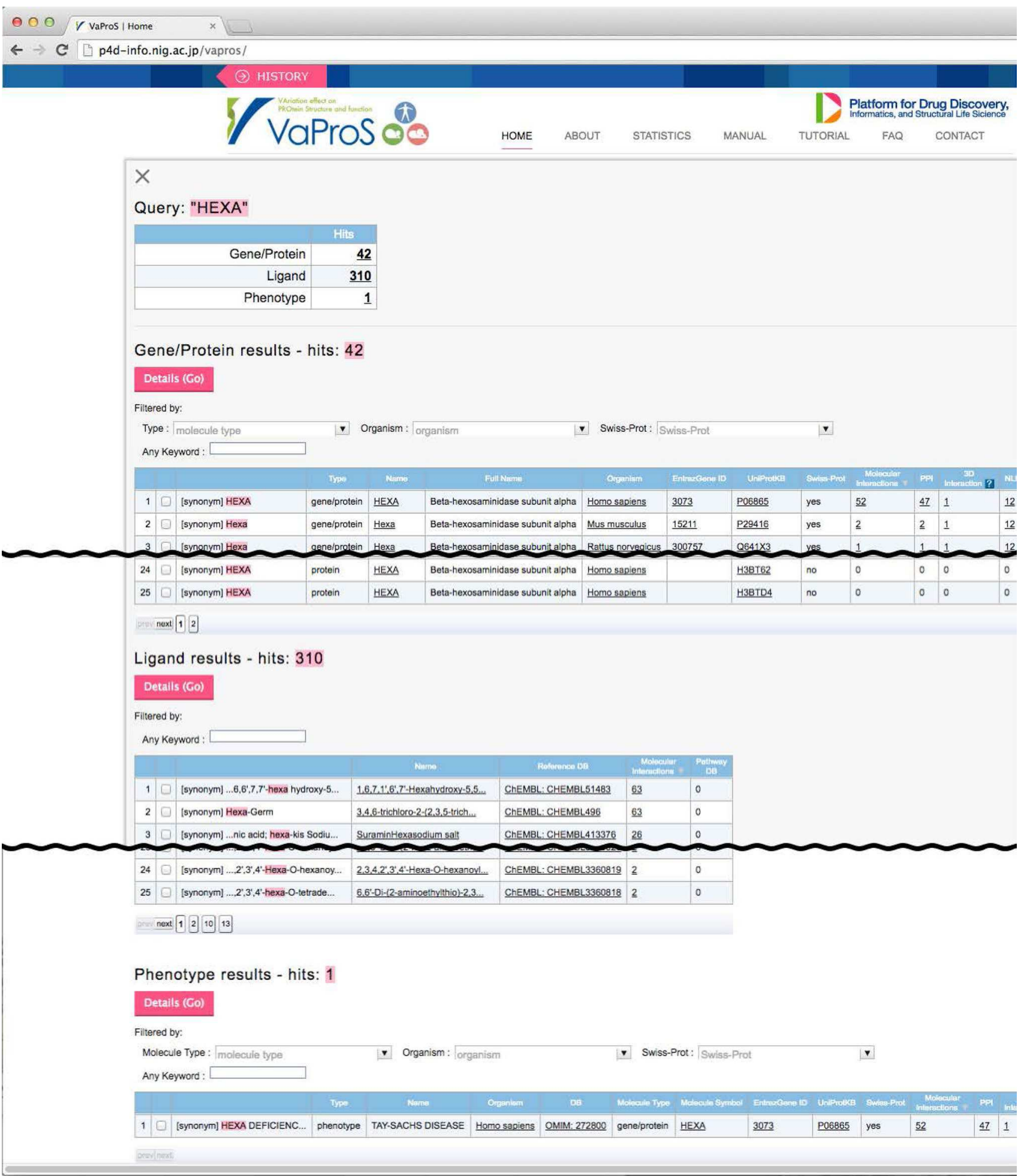

Fig. 2 The initial search result by VaProS. The query word is "HEXA", the causative gene of Tay-Sachs disease

databases listed in Table 1. In Fig. 5, the nodes in red are proteins associated with diseases. The information was extracted from OMIM (Table 1), and the catalog of specific disease is given on the right side of the window.
There are two nodes in red that interact with both HEXA and HEXB, which suggest disease-disease interactions. By right clicking a node, protein-protein interactions can be extended. The pathway of two nodes in the window 


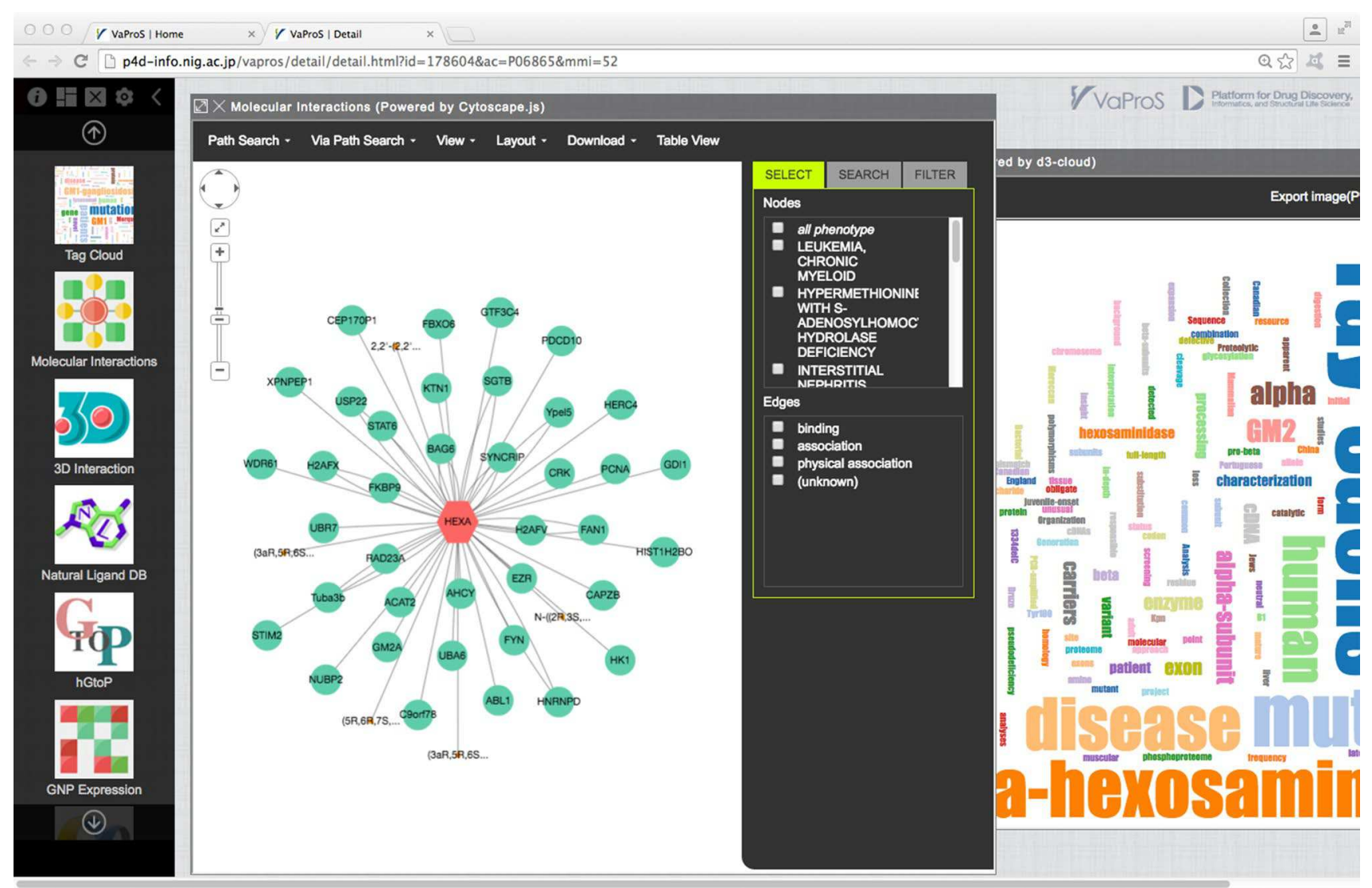

Fig. 3 The search result in detail by pressing the "Details (Go)" button in Fig. 2. The protein-protein interactions and frequently used terms in literature related to HEXA are displayed

can be automatically detected using "Path Search" on the top menu.

By clicking a node or an edge, the detail information of the node/edge can be displayed on the right bottom of the window. In Fig. 5, HEXA was selected, hence the detail of HEXA was presented on the right. The link to "3D Interaction" shows the protein 3D structural information of HEXA protein. In 3D Interaction, SiteTable/SitesByVariants link leads the users to the information that VaProS aims for, namely the relationship between variations on DNA and protein structure/function.

\section{TagCloud}

An overview of the target protein can be obtained by analyzing the frequency of words in the manuscripts related to the protein. Figure 6 is the result of such analysis on the titles of papers registered in UniProtKB under the entry HEXA. TagCloud emphasizes words that frequently appear in the titles of these papers by enlarging the size of the fonts. Visual inspection of TagCloud makes us recognize that HEXA protein is beta-hexosaminidase and may be a multimeric protein. TagCloud also ascertains that the protein is connected with the notion of disease. These facts are trivial for specialists in the field, but are not so for the researchers in different fields and are valuable information for the interdisciplinary study. The list of the papers using the word in the title can be found by clicking the word in the TagCloud.

\section{hGtoP}

hGtoP provides relationship between genes and proteins as its name suggested ( $\mathrm{G}$ in hGtoP stands for Gene/Genome and $\mathrm{P}$ for Protein). The original GtoP was developed by Kawabata et al. [24]. VaProS included human specific GtoP as one of the tools. With hGtoP, the structural information of the protein in the query is easily found. In addition, the homologues of the protein in different species can be found. "3D Interaction" and "hGtoP" contain similar information about protein 3D structures, however, the former focuses more on 3D modelling of complex structures, and the latter focuses on comparative genomics. PDB information in Table 2 was obtained by hGtoP and 3D Interaction. The information clarified that some of the proteins in LSDs do not have structural information yet. In other 
Table 2 Lysosomal storage diseases

\begin{tabular}{|c|c|c|c|c|c|}
\hline Disease & Type & Gene & UniProt ID & PDB & PDB identity* \\
\hline \multirow[t]{13}{*}{ Mucopolysaccharidosis } & IH (Hurler syndrome) & - & - & - & - \\
\hline & IH-S (Hurler-Scheie syndrome) & IDUA & IDUA_HUMAN & $3 \mathrm{~W} 81$ & $100 \%$ \\
\hline & IS (Hurler, Hurler/Scheie, Scheie syndrome) & - & - & - & - \\
\hline & II (Hunter syndrome) & IDS & IDS_HUMAN & 4UG4 & $36 \%$ \\
\hline & III-A (Sanfilippo syndrome) & SGSH & SPHM_HUMAN & 4MIV & $100 \%$ \\
\hline & III-B & NAGLU & ANAG_HUMAN & $4 \mathrm{XWH}$ & $100 \%$ \\
\hline & III-C & HGSNAT & HGNAT_HUMAN & - & - \\
\hline & III-D & GNS & GNS_HUMAN & 4UG4 & $30 \%$ \\
\hline & IV-A (Morquio syndrome) & GALNS & GALNS_HUMAN & 4FDI & $100 \%$ \\
\hline & IV-B & GLB1 & BGAL_HUMAN & $3 \mathrm{WF} 2$ & $100 \%$ \\
\hline & VI (Maroteaux-Lamy syndrome) & ARSB & ARSB_HUMAN & $1 \mathrm{FSU}$ & $100 \%$ \\
\hline & VII (Sly syndrome) & GUSB & BGLR_HUMAN & $1 \mathrm{BHG}$ & $100 \%$ \\
\hline & IX (Hyaluronidase deficiency) & HYAL1 & HYAL1_HUMAN & 2PE4 & $99 \%$ \\
\hline \multirow[t]{4}{*}{ Niemann-Pick disease } & A & SMPD1 & ASM_HUMAN & $5 \mathrm{FC} 5$ & $35 \%$ \\
\hline & B & - & - & - & - \\
\hline & $\mathrm{C} 1$ & NPC1 & NPC1_HUMAN & 3JD8 & $100 \%$ \\
\hline & $\mathrm{C} 2$ & NPC2 & NPC2_HUMAN & 2HKA & $80 \%$ \\
\hline \multirow[t]{3}{*}{ GM1 gangliosidosis } & I & GLB1 & BGAL_HUMAN & $3 \mathrm{WF} 2$ & $100 \%$ \\
\hline & II & GLB1 & BGAL_HUMAN & $3 \mathrm{WF} 2$ & $100 \%$ \\
\hline & III & GLB1 & BGAL_HUMAN & $3 \mathrm{WF} 2$ & $100 \%$ \\
\hline \multirow[t]{3}{*}{ GM2 gangliosidosis } & Tay-Sachs disease & HEXA & HEXA_HUMAN & $2 \mathrm{GJX}$ & $99 \%$ \\
\hline & Sandhoff's disease & HEXB & HEXB_HUMAN & $5 \mathrm{BRO}$ & $98 \%$ \\
\hline & $\mathrm{AB}$ variant & GM2A & SAP3_HUMAN & 1PUB & $100 \%$ \\
\hline \multirow[t]{4}{*}{ Sulfatide lipidosis } & Metachromatic leukodystrophy & ARSA & ARSA_HUMAN & $1 \mathrm{~N} 2 \mathrm{~L}$ & $100 \%$ \\
\hline & & ARSA & ARSA_HUMAN & $1 \mathrm{~N} 2 \mathrm{~L}$ & $100 \%$ \\
\hline & Multiple sulfatase Deficiency & ARSB & ARSB_HUMAN & $1 \mathrm{FSU}$ & $100 \%$ \\
\hline & & SUMF1 & SUMF1_HUMAN & $1 \mathrm{Y} 1 \mathrm{H}$ & $100 \%$ \\
\hline \multirow[t]{4}{*}{ Saposin dificiency } & Prosaposin deficiency & - & - & $4 \mathrm{~V} 2 \mathrm{O}$ & \multirow{4}{*}{$\begin{array}{l}100 \% \text { (frag- } \\
\text { ments) }\end{array}$} \\
\hline & Krabbe disease, atypical & - & - & 3BQQ & \\
\hline & Saposin B deficiency & PSAP & SAP_HUMAN & 2DOB & \\
\hline & Gaucher disease, atypical & - & - & 1SN6 & \\
\hline Glycogenosis & II (Pompe disease) & GAA & LYAG_HUMAN & 2QLY & $47 \%$ \\
\hline Gaucher disease & Gaucher disease & GBA & GLCM_HUMAN & $2 \mathrm{WKL}$ & $100 \%$ \\
\hline Fabry disease & Fabry disease & GLA & AGAL_HUMAN & $3 \mathrm{LXB}$ & $99 \%$ \\
\hline Ceramidosis & Farber's disease & ASAH1 & ASAH1_HUMAN & - & - \\
\hline Krabbe disease & Krabbe disease & GALC & GALC_HUMAN & 4UFH & $84 \%$ \\
\hline Cholesterol ester storage disease & Cholesterol ester storage disease & LIPA & LICH_HUMAN & $1 \mathrm{~K} 8 \mathrm{Q}$ & $60 \%$ \\
\hline Wolman disease & Wolman disease & & & & \\
\hline \multirow[t]{9}{*}{ Glycoprotein disorder } & Alpha-fucosidosis & FUCA1 & FUCO_HUMAN & $2 \mathrm{ZXA}$ & $39 \%$ \\
\hline & Alpha-mannosidosis & MAN2B1 & MA2B1_HUMAN & 1O7D & $83 \%$ \\
\hline & Beta-mannosidosis & MANBA & MANBA_HUMAN & 2VR4 & $31 \%$ \\
\hline & Aspartylglycosaminuria & AGA & ASPG_HUMAN & $1 \mathrm{APZ}$ & $99 \%$ \\
\hline & Galactosialidosis & CTSA & PPGB_HUMAN & $1 \mathrm{IVY}$ & $99 \%$ \\
\hline & Mucolipidosis I & NEU1 & NEUR1_HUMAN & 1EUS & $37 \%$ \\
\hline & Mucolipidosis II & - & - & - & - \\
\hline & Mucolipidosis III & GNPTAB & GNPTA_HUMAN & 2N6D & $99 \%$ (fragment) \\
\hline & Schindler's disease & NAGA & NAGAB_HUMAN & 4DO4 & $99 \%$ \\
\hline
\end{tabular}


Table 2 (continued)

\begin{tabular}{|c|c|c|c|c|c|}
\hline Disease & Type & Gene & UniProt ID & PDB & PDB identity* \\
\hline \multirow[t]{5}{*}{ Membrane metabolism disorder } & Cystinosis & CTNS & CTNS_HUMAN & - & - \\
\hline & Sialic acid storage disease (Salla disease) & SLC17A5 & S17A5_HUMAN & - & - \\
\hline & $\begin{array}{l}\text { Cathepsin K deficiency disease (pycnodys- } \\
\text { ostosis) }\end{array}$ & CTSK & CATK_HUMAN & 7PCK & $100 \%$ \\
\hline & Cobalamin F disease (cblF) & LMBRD1 & LMBD1_HUMAN & - & - \\
\hline & Danon disease & LAMP2 & LAMP2_HUMAN & 2MOM & $100 \%$ (fragment) \\
\hline \multirow[t]{14}{*}{ Neuronal Ceroid Lipofuscinosis } & Neuronal ceroid lipofuscinosis-1 & PPT1 & PPT1_HUMAN & $3 \mathrm{GRO}$ & $100 \%$ \\
\hline & Neuronal ceroid lipofuscinosis-2 & TPP1 & TPP1_HUMAN & 3EDY & $100 \%$ \\
\hline & Neuronal ceroid lipofuscinosis- 3 & CLN3 & CLN3_HUMAN & - & - \\
\hline & Neuronal ceroid lipofuscinosis-4A & CLN6 & CLN6_HUMAN & - & - \\
\hline & Neuronal ceroid lipofuscinosis-4B & DNAJC5 & DNJC5_HUMAN & $2 \mathrm{CTW}$ & $100 \%$ (fragment) \\
\hline & Neuronal ceroid lipofuscinosis-5 & CLN5 & CLN5_HUMAN & - & - \\
\hline & Neuronal ceroid lipofuscinosis-6 & CLN6 & CLN6_HUMAN & - & - \\
\hline & Neuronal ceroid lipofuscinosis-7 & MFSD8 & MFSD8_HUMAN & - & - \\
\hline & Neuronal ceroid lipofuscinosis- 8 & CLN8 & CLN8_HUMAN & - & - \\
\hline & Neuronal ceroid lipofuscinosis-10 & CTSD & CATD_HUMAN & 2PSG & $49 \%$ \\
\hline & Neuronal ceroid lipofuscinosis-11 & GRN & GRN_HUMAN & 2JYE & $100 \%$ (fragment) \\
\hline & Neuronal ceroid lipofuscinosis-12 & ATP13A2 & AT132_HUMAN & 3WGV & $27 \%$ \\
\hline & Neuronal ceroid lipofuscinosis-13 & CTSF & CATF_HUMAN & $1 \mathrm{M} 6 \mathrm{D}$ & $99 \%$ \\
\hline & Neuronal ceroid lipofuscinosis-14 & KCTD7 & KCTD7_HUMAN & 4UES & $50 \%$ (fragment) \\
\hline Congenital disorder of glycosylation & IA & PMM2 & PMM2_HUMAN & 2AMY & $100 \%$ \\
\hline
\end{tabular}

*Amino acid sequence identity between the UniProt and PDB entries

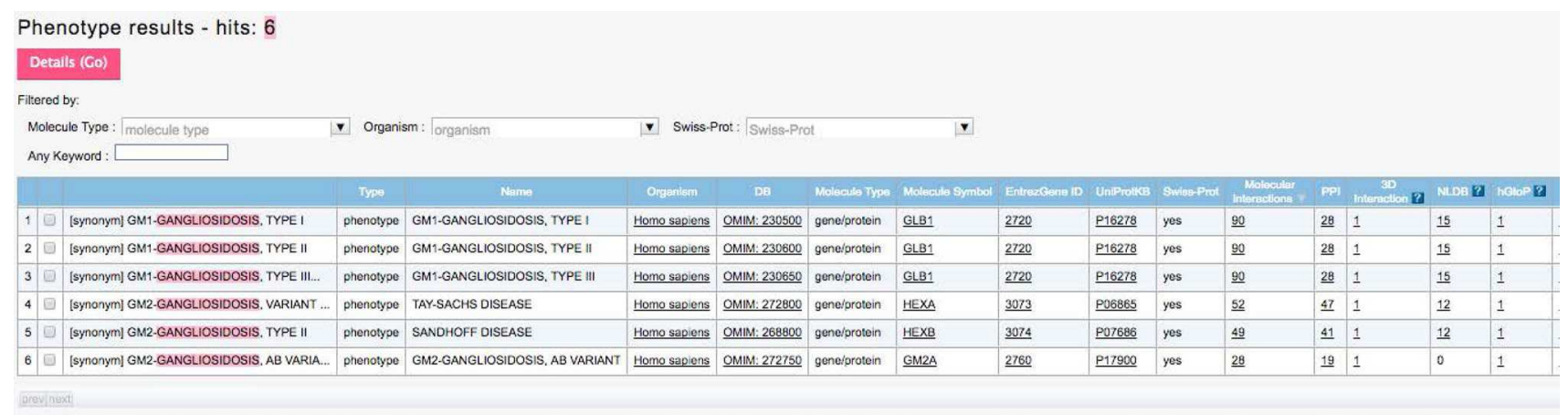

Fig. 4 Initial search result by VaProS. The search by "gangliosidosis" initially results in a table of candidates

words, Table 2 provides valuable information for structural genomes of LSDs, namely the target proteins for determining 3D structures.

\section{Natural ligand database}

Natural Ligand Database (NLDB) [25] provides the model of protein structures with natural ligands. The idea stemmed from the fact that many ligands in PDB are modified ligands for the sake of crystallisation and the bridge between those modified ligands and natural ligands should be provided to enhance the $3 \mathrm{D}$ structural information in
PDB. The search query "GM1 gangliosidosis" led the user to the causative gene GLB1. NLDB demonstrated that GLB1 was involved in 15 KEGG reactions, and these 15 reactions were classified into five pathways according to "UniProt search view". The same 15 reactions can be found in "Pathway DB" tool (Table 1). Of the five pathways in NLDB, glycosphingolipid biosynthesis (hsa00604) contained the reaction of GM1 degradation (R06010). In this reaction, 56 natural ligand complexes were registered in NLDB derived from the proteins of various species. The link to human beta-galactosidase, the product of GLB1 gene, with galactose (PDB ID: 3THC) led to the 3D 


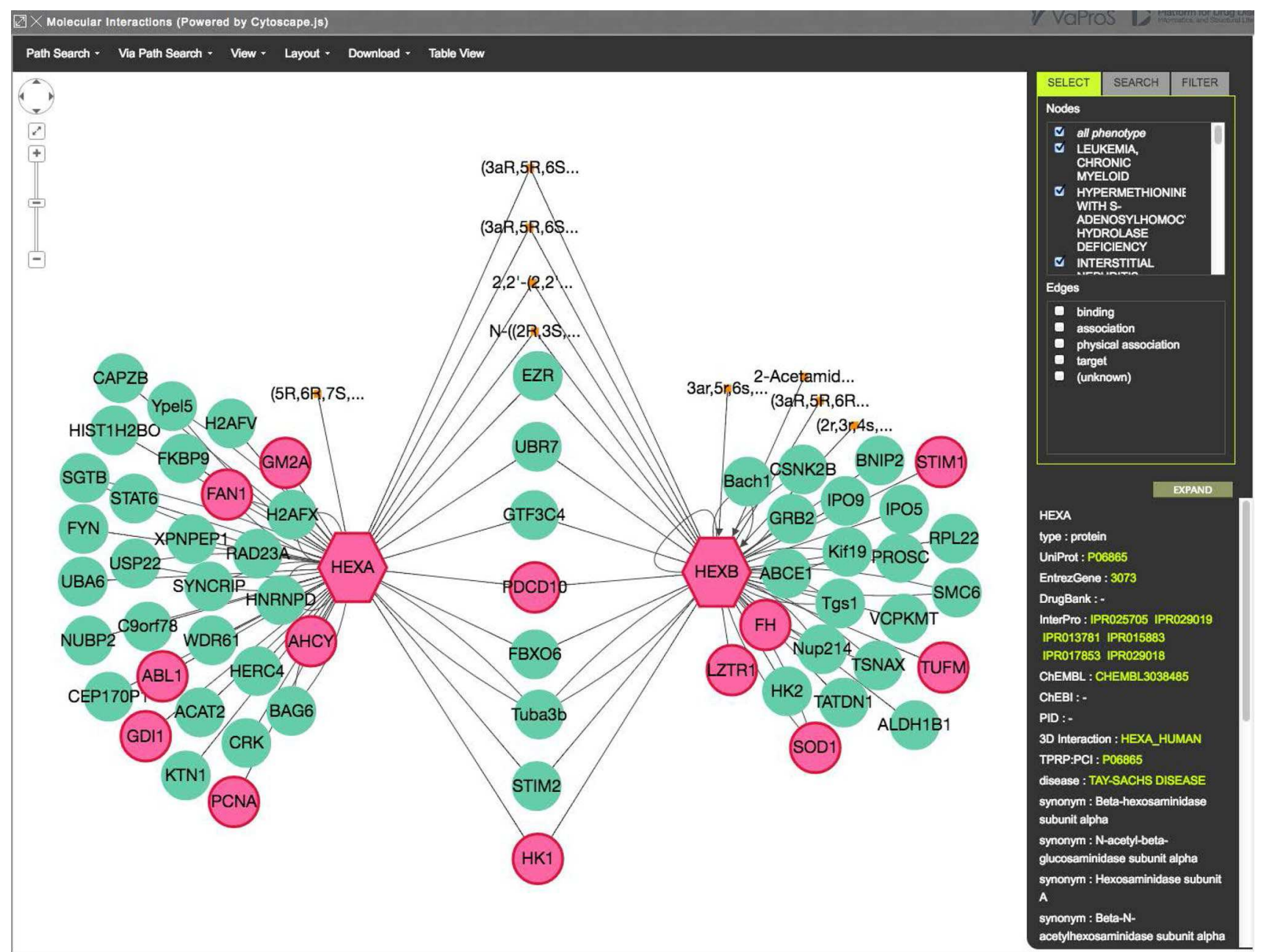

Fig. 5 "Molecular Interactions" after selecting HEXA and HEXB in the initial search result (Fig. 4). A big node represents a protein, a small node represents a ligand and an edge represents a protein-pro- tein/ligand interaction. A node in red is associated with a disease (selected in the top-right window) structures of the ligand-protein complex with reported variation in amino acid residues. The variations in amino acid residues around the ligand-binding site were highlighted on the table of NLDB window. In this entry, ten variations were reported around the ligand-binding site, and eight of them were related to diseases, namely three to GM1 type I, one to GM1 type II, one to GM1 type III, and two to mucopolysaccharidosis IV-B.

\section{COXPRESdb}

Gene co-expression sometimes sheds light on relationship between genes, and COXPRESdb [26] provides userfriendly interface to gene co-expression information in humans, mice and rats. The search query "GM2 gangliosidosis" on VaProS led the user to a list of causative genes that included HEXA and HEXB. COXPRESdb demonstrated that the co-expression for HEXA $(\mathrm{PCC}=0.43)$ and HEXB ( $\mathrm{PCC}=0.45)$, which are known to be related with Sandhoff disease and Tay-Sachs disease, respectively from OMIM information. By following the link to COXPRESdb, the user can also check the co-expression networks of HEXA and HEXB, which led to the finding that ten more lysosomal proteins are tightly co-expressed with them.

\section{Other tools}

GNP Expression, Phenotype, Autophagy DB, Genome Explorer and Mutation@A Glance (Table 1) show the search results in a tabulated or graphical form. The user can further analyze the database of each tool by following the link in the search result. 
Fig. 6 Artistic representation of the frequency of words in the titles of the manuscripts stored in the entry of HEXA_HUMAN in UniProtKB. The visualization was realized by $\mathrm{d} 3$-cloud (https://github.com/jasondavies/ d3-cloud)

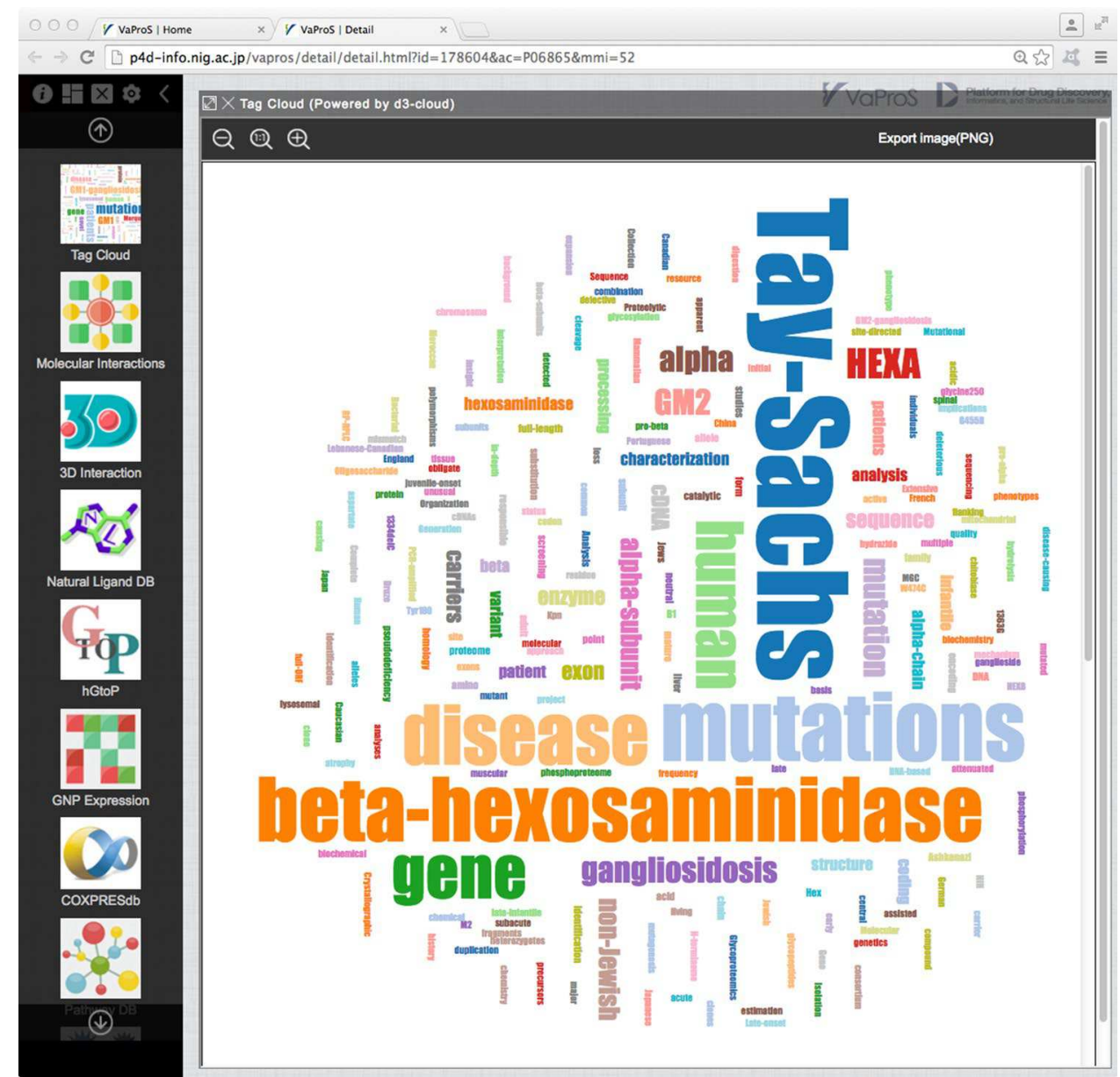

S-VAR is a special tool that evaluates impact of amino acid substitution to the function of the protein. By providing a specific mutation to the window of S-VAR, the tool starts a couple of software that evaluate the impact of the mutation [33-36] and provides each and consensus results for the user at some intervals.
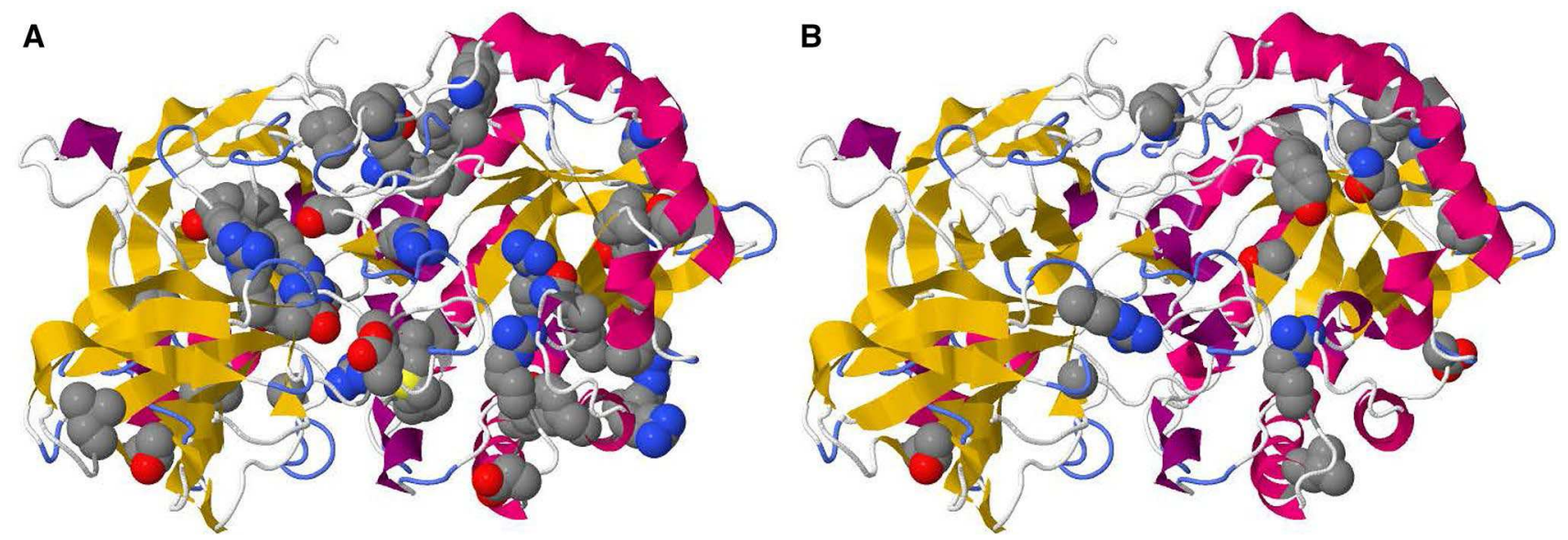

Fig. 7 Variations of GM1-gangliosidosis mapped onto the protein 3D structure of GLB1. Variations in type I (a) and variations in type III (b). The structure of human $\beta$-galactosidase (PDB ID: $3 \mathrm{WF} 2$ ) is used for the mapping 
Table 3 Summary of the mutated sites of GLB1 on protein 3D structure for GM1gangliosidosis

\begin{tabular}{lllll}
\hline & GM1 type I & GM1 type II & GM1 type III & All residues \\
\hline Number of residues $^{\text {a }}$ & 45 & 17 & 15 & 677 \\
Buried residue $\left.^{\mathrm{a}} \%\right)$ & 95.5 & 88.2 & 86.7 & 56.8 \\
Exposed residue $^{\mathrm{b}}(\%)$ & 4.5 & 11.8 & 13.3 & 43.2 \\
\hline
\end{tabular}

${ }^{a}$ Residue with relative solvent accessibility less than $20 \%$.

${ }^{\mathrm{b}}$ Residue with relative solvent accessibility no less than $20 \%$.

\section{Building hypothesis on the relationship between phenotype and protein 3D structure}

Combination of the search results in each tool can be a basis of building a hypothesis that can be verified by wet-lab experiments. The search query "GM1 gangliosidosis" on VaProS led the user to the current knowledge that the causative gene is GLB1, which encodes lysosomal enzyme $\beta$-D-galactosidase. By following the link to OMIM [7], user can acquire information on the detail of the disease, namely GM1 gangliosidosis is classified into three types in accordance with the onset age and severity; type I (infantile), type II (juvenile) and type III (adult) as shown in Table 2.

"3D Interaction" summarized the variations leading to each type of diseases on the protein 3D structure (Fig. 7). Visual inspection of the figure tells that the variation tends to be located inside the protein. Indeed, the ratios of buried residues for type I was $95.5 \%$, for type II was $88.2 \%$, and for type III was $86.7 \%$. These ratios are significantly higher than the average of the protein (Table 3 ). Note that the ratio of buriedness of the variation site is highest in type I and lowest in type III. Generally, mutations on the buried sites often make the protein less stable than the native one. Hence the observation suggests that the variations on type I have more impact on the stability of the protein than those on type III. 3D Interaction also provided amino acid frequencies of homologous proteins. The mutation to the rare amino acid implies that the type of amino acid has not sufficiently fixed during the molecular evolution. The ratios of mutations to the amino acids that no homologues used were $78.4 \%$ (type I), $73.7 \%$ (type II) and 53.3\% (type III). Serious phenotypes are expected by mutations to amino acid types rarely observed in homologues. The buriedness and trends in amino acid types between types I and III apparently correlated with the degree of seriousness in each type of GM1 gangliosidoses. The similar trend was discussed by Ohto et al. at the time they determined the 3D structure of the protein [37]. VaProS enables such complex hypothesis building in a short period of time.

\section{Conclusion}

Here we launched VaProS, a new type of database integration application. VaProS enables a quick search of multiple databases with interrelation of each search result. This application can be used as a textbook for acquiring expert knowledge for researchers in different fields, and can be a tool for building a data-driven hypothesis that can be tested by wet-lab experiments [16-23].

Acknowledgements This research is supported by the Platform Project for Supporting in Drug Discovery and Life Science Research (Platform for Drug Discovery, Informatics, and Structural Life Science) from Japan Agency for Medical Research and Development (AMED).

Open Access This article is distributed under the terms of the Creative Commons Attribution 4.0 International License (http:// creativecommons.org/licenses/by/4.0/), which permits unrestricted use, distribution, and reproduction in any medium, provided you give appropriate credit to the original author(s) and the source, provide a link to the Creative Commons license, and indicate if changes were made.

\section{References}

1. Benson DA, Cavanaugh M, Clark K, Karsch-Mizrachi I, Lipman DJ, Ostell J, Sayers EW (2013) Nucleic Acids Res 41:D36-D42

2. Cook CE, Bergman MT, Finn RD, Cochrane G, Birney E, Apweiler R (2016) Nucleic Acids Res 44:D20-D26

3. Mashima J, Kodama Y, Kosuge T, Fujisawa T, Katayama T, Nagasaki H, Okuda Y, Kaminuma E, Ogasawara O, Kokubo K, Nakamura Y, Takagi T (2016) Nucleic Acids Res 44:D51-D57

4. Barrett T, Wilhite SE, Ledoux P, Evangelista C, Kim IF, Tomashevsky M, Marshall KA, Phillippy KH, Sherman PM, Holko M, Yefanov A, Lee H, Zhang N, Robertson CL, Serova N, Davis S, Soboleva An (2013) Nucleic Acids Res 41:D991-D995

5. Sherry ST, Ward MH, Kholodov M, Baker J, Phan L, Smigielski EM, Sirotkin K (2001) Nucleic Acids Res 29:308-311

6. Berman H, Henrick K, Nakamura H (2003) Nat Struct Mol Biol 10:980

7. Online Mendelian Inheritance in Man, OMIM. McKusickNathans Institute of Genetic Medicine, Johns Hopkins University (Baltimore, MD). http://omim.org/

8. Gewin V (2015) Nature 529:117-119

9. Camacho C, Coulouris G, Avagyan V, Ma N, Papadopoulos J, Bealer K, Madden TL (2009) BMC Bioinform 10:421 
10. Wikipedia (2016). http://en.wikipedia.org/wiki/Wikipedia

11. NCBI Resource Coordinators (2013) Nucleic Acids Res 41:D8-D20

12. Stelzer G, Dalah I, Iny Stein T, Satanower Y, Rosen N, Nativ N, Oz-Levi D, Olender T, Belinky F, Bahir I, Krug H, Perco P, Mayer B, Kolker E, Safran M, Lancet D (2011) Hum Genom 5:709-717

13. Forbes SA, Beare D, Gunasekaran P, Leung K, Bindal N, Boutselakis H, Ding M, Bamford S, Cole C, Ward S, Kok CY, Jia M, De T, Teague JW, Stratton MR, McDermott U, Campbell PJ (2015) Nucleic Acids Res 43:D805-D811

14. Katayama T, Wilkinson MD, Micklem G, Kawashima S, Yamaguchi A, Nakao M, Yamamoto Y, Okamoto S, Oouchida K, Chun H-W, Aerts J, Afzal H, Antezana E, Arakawa K, Aranda B, Belleau F, Bolleman J, Raoul Bonnal J, Chapman B, Peter Cock J, Eriksson T, Paul Gordon M, Goto N, Hayashi K, Horn H, Ishiwata R, Kaminuma E, Kasprzyk A, Kawaji H, Kido N, Young Kim J, Kinjo AR, Konishi F, Kwon K-H, Labarga A, Lamprecht A-L, Lin Y, Lindenbaum P, McCarthy L, Morita H, Murakami K, Nagao K, Nishida K, Nishimura K, Nishizawa T, Ogishima S, Ono K, Oshita K, Park K-J, Prins P, Saito TL, Samwald M, Satagopam VP, Shigemoto Y, Smith R, Splendiani A, Sugawara H, Taylor J, Vos RA, Withers D, Yamasaki C, Zmasek CM, Kawamoto S, Okubo K, Asai K, Takagi T (2013) J Biomed Semant $4: 1-17$

15. Katayama T, Wilkinson MD, Aoki-Kinoshita KF, Kawashima S, Yamamoto Y, Yamaguchi A, Okamoto S, Kawano S, Kim J-D, Wang Y, Wu H, Kano Y, Ono H, Bono H, Kocbek S, Aerts J, Akune Y, Antezana E, Arakawa K, Aranda B, Baran J, Bolleman J, Bonnal RJ, Buttigieg PL, Campbell MP, Chen Y-a, Chiba H, Cock PJ, Cohen KB, Constantin A, Duck G, Dumontier M, Fujisawa T, Fujiwara T, Goto N, Hoehndorf R, Igarashi Y, Itaya H, Ito M, Iwasaki W, Kalas M, Katoda T, Kim T, Kokubu A, Komiyama Y, Kotera M, Laibe C, Lapp H, Lutteke T, Marshall MS, Mori T, Mori H, Morita M, Murakami K, Nakao M, Narimatsu $\mathrm{H}$, Nishide H, Nishimura Y, Nystrom-Persson J, Ogishima S, Okamura Y, Okuda S, Oshita K, Packer NH, Prins P, Ranzinger R, Rocca-Serra P, Sansone S, Sawaki H, Shin S-H, Splendiani A, Strozzi F, Tadaka S, Toukach P, Uchiyama I, Umezaki M, Vos R, Whetzel PL, Yamada I, Yamasaki C, Yamashita R, York WS, Zmasek CM, Kawamoto S, Takagi T (2014) J Biomed Semant 5:1-13

16. NCBI Resource Coordinators (2016) Nucleic Acids Res 44:D7-19

17. The UniProt Consortium (2014) Nucleic Acids Res 43:D204-D212

18. Chatr-aryamontri A, Breitkreutz BJ, Oughtred R, Boucher L, Heinicke S, Chen D, Stark C, Breitkreutz A, Kolas N, O'Donnell L, Reguly T, Nixon J, Ramage L, Winter A, Sellam A, Chang C, Hirschman J, Theesfeld C, Rust J, Livstone MS, Dolinski K, Tyers M (2015) Nucleic Acids Res 43:D470-D478

19. Bento AP, Gaulton A, Hersey A, Bellis LJ, Chambers J, Davies M, Kruger FA, Light Y, Mak L, McGlinchey S, Nowotka M,
Papadatos G, Santos R, Overington JP (2014) Nucleic Acids Res 42:D1083-D1090

20. Law V, Knox C, Djoumbou Y, Jewison T, Guo AC, Liu Y, Maciejewski A, Arndt D, Wilson M, Neveu V, Tang A, Gabriel G, Ly C, Adamjee S, Dame ZT, Han B, Zhou Y, Wishart DS (2014) Nucleic Acids Res 42:D1091-D1097

21. Kerrien S, Aranda B, Breuza L, Bridge A, Broackes-Carter F, Chen C, Duesbury M, Dumousseau M, Feuermann M, Hinz U, Jandrasits C, Jimenez RC, Khadake J, Mahadevan U, Masson P, Pedruzzi I, Pfeiffenberger E, Porras P, Raghunath A, Roechert B, Orchard S, Hermjakob H (2011) Nucleic Acids Res 40:D841-D846

22. Pratt D, Chen J, Welker D, Rivas R, Pillich R, Rynkov V, Ono K, Miello C, Hicks L, Szalma S, Stojmirovic A, Dobrin R, Braxenthaler M, Kuentzer J, Demchak B, Ideker T (2015) Cell Syst 1:302-305

23. Fabregat A, Sidiropoulos K, Garapati P, Gillespie M, Hausmann K, Haw R, Jassal B, Jupe S, Korninger F, McKay S, Matthews L, May B, Milacic M, Rothfels K, Shamovsky V, Webber M, Weiser J, Williams M (2016) Nucleic Acids Res 44:D481-D487

24. Kawabata T, Fukuchi S, Homma K, Ota M, Araki J, Ito T, Ichiyoshi N, Nishikawa K (2002) Nucleic Acids Res 30:294-298

25. Murakami Y, Omori S, Kinoshita K (2016) J Struct Funct Genomics doi:10.1007/s10969-016-9206-0

26. Okamura Y, Aoki Y, Obayashi T, Tadaka S, Ito S, Narise T, Kinoshita K (2015) Nucleic Acids Res 43:D82-D86

27. Hijikata A, Raju R, Keerthikumar S, Ramabadran S, Balakrishnan L, Ramadoss SK, Pandey A, Mohan S, Ohara O (2010) DNA Res 17:197-208

28. Kawabata T (2016) J Struct Funct Genom. doi:10.1007/ s10969-016-9208-y

29. Homma K, Suzuki K, Sugawara H (2011) Nucleic Acids Res 39:D986-D990

30. Meikle PJ, Hopwood JJ, Clague AE, Carey WF (1999) J Am Med Assoc 281:249-254

31. Poorthuis BJ, Wevers RA, Kleijer WJ, Groener JE, de Jong JG, van Weely S, Niezen-Koning KE, van Diggelen OP (1999) Hum Genet 105:151-156

32. Brunetti-Pierri N, Scaglia F (2008) Mol Genet Metab 94:391-396

33. Adzhubei IA, Schmidt S, Peshkin L, Ramensky VE, Gerasimova A, Bork P, Kondrashov AS, Sunyaev SR (2010) Nat Methods 7:248-249

34. Kumar P, Henikoff S, Ng PC (2009) Nat Protoc 4:1073-1081

35. Choi Y, Sims GE, Murphy S, Miller JR, Chan AP (2012) PLoS one 7:e46688

36. Thomas PD, Campbell MJ, Kejariwal A, Mi H, Karlak B, Daveman R, Diemer K, Muruganujan A, Narechania A (2003) Genome Res 13:2129-2141

37. Ohto U, Usui K, Ochi T, Yuki K, Satow Y, Shimizu T (2012) J Biol Chem 287:1801-1812 